\title{
Synthesis and Spectral Study of New Mercerized Azodyes and their Complexes with Copper(II)
}

\author{
TAREK A. FAHAD*, ASSAD A. ALI and HAWRAA K. EBRAHEEM \\ Department of Chemistry, Edu. College of Pure Sci. University of Basra, Basra, Iraq \\ tarek_albarah2005@yahoo.com
}

Received 14 January 2013 / Accepted 15 February 2013

\begin{abstract}
A new series of some mercerized azodyes, 2-( 2-mercury chloride -4-X phenylazo)-4acetamido phenol (where $\mathrm{X}=$ sulphonic acid $\left[\mathrm{L}_{1}\right]$, acetyl $\left[\mathrm{L}_{2}\right]$,carboxyl $\left[\mathrm{L}_{3}\right]$, nitro $\left[\mathrm{L}_{4}\right]$ and sulphamide $\left[\mathrm{L}_{5}\right]$ ) were prepared. All these were characterized by melting points, FT IR-spectroscopy ${ }^{1} \mathrm{H}$ NMR and $\mathrm{C} \mathrm{H} \mathrm{N}$ analysis. The work involves a study of acid - base properties at different $\mathrm{pH}$ values, the ionization and protonation constants were calculated. The complexes of $\mathrm{L}_{1}$ and $\mathrm{L}_{5}$ with $\mathrm{Cu}(\mathrm{II})$ were prepared. These complexes have been concluding after fixing the optimum conditions (time, $\mathrm{pH}$ and sequence of addition effects). The spectra of the complexes solutions have been studied for a range of concentrations which Lambert - Beer's law obeyed. It was found that the complexes are 1: 2 (M:L) complexes and the overall stability constants were determined by the corresponding solutions method
\end{abstract}

Keywords: Mercerized azodyes, 4-Acetamido phenol, Mercerized aniline

\section{Introduction}

Azo compounds have been receiving much attention and have been widely used in many practical application such as coloring fiber ${ }^{1}$ clothing $^{2}$, cosmetics ${ }^{3}$, plastics ${ }^{4}$, self-colored segmented polymeric dyes ${ }^{5}$. Anti corrosion ${ }^{6}$, azo metal chelats have also attracted increase attention due to their interesting electronic and geometrical features in connection with their application for molecular memory storages, nonlinear optical elements printing system ${ }^{7}$, drug, cosmetic and photochemical production ${ }^{8}$. Azo dyes of sulfa drugs are well known for their antiseptic activity ${ }^{9}$ and some are useful as chemotherapeutic agents ${ }^{10}$.

Organomercurials have been used extensively in organic synthesis as well as in mechanism investigation due to their ability to accommodate practically all of the important organic functional groups and their ease in undergoing transmetallation for the synthesis of other organ metallic compounds ${ }^{11}$, organomercurials, coupled with heterocyclic compounds exhibit a wide range of pharmacological activities like fungicidal, bactericidal ${ }^{12,13}$.

In the present investigation concerned with preparation five new mercerized azodyes by reaction of paracetamol (4-acetamido phenol) with 2-mercury chloride -4-X-aniline. The characterization of the azo compounds has been performed by IR, NMR and C H N and their complexes with copper. 


\section{Experimental}

All the reagents and solvents were of reagent-grad quality. The progress of reaction was monitored by TLC using silica gel coated plates $(0.5 \mathrm{~mm}$ thickness, Merck) and spots were visualized under UV radiation. Infrared spectra (in $\mathrm{K} \mathrm{Br}$ pellets) were recorded on FT IR8400S shimadzu. NMR spectra were recorded by Bruker Ultra Shield $300 \mathrm{MHz}$ spectrometer DMSO as solvent and TMS as internal reference. Melting point we determined on melting point apparatus. The elemental analysis $(\mathrm{C}, \mathrm{H}, \mathrm{N})$ were carried out on a microanalysis unit of Perkin Elmer model 2400 and given in Table 1. UV-Vis. absorption spectra of the dyes in different buffer solutions at room temperature were recorded using Hitachi UL-1500 spectrophotometer.

2-Mercury chloride $-4-X$ aniline (where $\mathrm{X}=$ sulphonic acid, acetyl, carboxyl, nitro and sulphamide) were prepared from 2-mercury chloride-4-X aniline and mercuric acetate according to literature method ${ }^{14}$.

\section{Synthesis of dyes}

\section{Diazotization}

2-Mercury chloride $-4-\mathrm{X}$ aniline $(0.02 \mathrm{~mol})$ was dissolved in $50 \mathrm{~mL}$ of distilled water and $6 \mathrm{~mL}$ of concentrated hydrochloric acid was added the solution was then cooled to $0-5{ }^{\circ} \mathrm{C}$ in ice-bath and maintained at this temperature sodium nitrate $(0.02 \mathrm{~mol})$ solution in $5 \mathrm{~mL}$ water was then added drop wise with stirring for $30 \mathrm{~min}$ to produce diazonium salt.

\section{Preparation of dyes}

The diazonium solution was added portion wise to the coupling component solution prepared by dissolving $0.02 \mathrm{~mol}$ of paracetomol(4-acetaminophenol) in $100 \mathrm{~mL}$ of alkaline solution. The mixture was stirred for further $1 \mathrm{~h}$ at $0{ }^{0} \mathrm{C}$ and then the mixture was neuteralized with dilute hydrochloric acid. The solid product was collected and washed with water until acid-free product and recrystallized from ethanol, dried at $50{ }^{\circ} \mathrm{C}$ in an oven to give azo dye (Scheme 1).

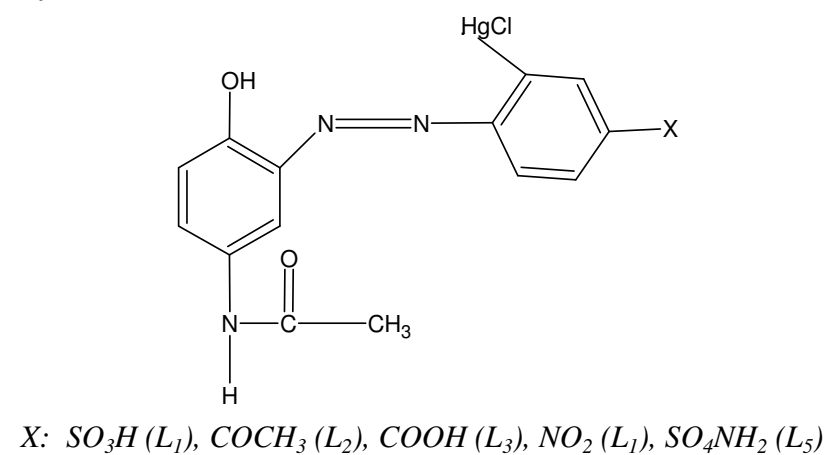

Scheme 1. Suggested molecular structure of dyes

A stock solutions of $\left(0.8 \times 10^{-4} \mathrm{M}\right)$ of each dyes were prepared by dissolving an accurately weighted amount of the compounds in the required volume of ethanol, more dilute solution were obtained by accurate dilution.

For acid-base studies the ionization (for hydroxyl group) and protonation (of nitrogen) constants of a series of acetate and universal buffer solutions were prepared with different $\mathrm{pH}$ values $(0.5-12)$ for each dyes ${ }^{15}$. 


\section{Results and Discussion}

The physical properties and elemental analysis data of the prepared dyes are listed in the Table 1.

Table 1. The physical and analytical data of the dyes

\begin{tabular}{|c|c|c|c|c|c|c|c|}
\hline \multirow{3}{*}{ Compd. } & \multirow{3}{*}{$\begin{array}{l}\text { Molecular } \\
\text { formula }\end{array}$} & \multirow{3}{*}{$\begin{array}{l}\text { M. } \\
\text { Wt. }\end{array}$} & \multirow{3}{*}{ Color } & \multirow{3}{*}{$\begin{array}{l}\text { M.P } \\
{ }^{\circ} \mathrm{C}\end{array}$} & \multicolumn{3}{|c|}{ Elemental analysis } \\
\hline & & & & & \multicolumn{3}{|c|}{ Composition, Found (Calcd.) } \\
\hline & & & & & $\% \mathrm{C}$ & $\% \mathrm{H}$ & $\% \mathrm{~N}$ \\
\hline $\mathrm{L}_{1}$ & $\mathrm{C}_{14} \mathrm{H}_{12} \mathrm{O}_{5} \mathrm{~N}_{3} \mathrm{SHgCl}$ & 570 & Orange & 331 & $\begin{array}{c}36,21 \\
(36.36)\end{array}$ & $\begin{array}{c}4.25 \\
(4.58)\end{array}$ & $\begin{array}{c}6.46 \\
(6.36)\end{array}$ \\
\hline $\mathrm{L}_{2}$ & $\mathrm{C}_{16} \mathrm{H}_{14} \mathrm{O}_{3} \mathrm{~N}_{3} \mathrm{HgCl}$ & 532 & RED & 183 & $\begin{array}{c}41.91 \\
(42.58)\end{array}$ & $\begin{array}{c}4.78 \\
(4.87)\end{array}$ & $\begin{array}{c}6.40 \\
(6.77)\end{array}$ \\
\hline $\mathrm{L}_{3}$ & $\mathrm{C}_{15} \mathrm{H}_{12} \mathrm{O}_{4} \mathrm{~N}_{3} \mathrm{HgCl}$ & 534 & range & 175 & $\begin{array}{c}39.25 \\
(39.41)\end{array}$ & $\begin{array}{c}4.11 \\
(4.47)\end{array}$ & $\begin{array}{c}6.76 \\
(6.89)\end{array}$ \\
\hline $\mathrm{L}_{4}$ & $\mathrm{C}_{14} \mathrm{H}_{11} \mathrm{O}_{4} \mathrm{~N}_{4} \mathrm{HgCl}$ & 535 & $\begin{array}{c}\text { Dark } \\
\text { Orange }\end{array}$ & 159 & $\begin{array}{c}37.02 \\
(37.44)\end{array}$ & $\begin{array}{c}4.01 \\
(4.13)\end{array}$ & $\begin{array}{c}8.98 \\
(9.19)\end{array}$ \\
\hline $\mathrm{L}_{5}$ & $\mathrm{C}_{14} \mathrm{H}_{13} \mathrm{O}_{4} \mathrm{~N}_{4} \mathrm{SHgCl}$ & 569 & Orange & 231 & $\begin{array}{c}35.23 \\
(35.46)\end{array}$ & $\begin{array}{c}4.12 \\
(4.23)\end{array}$ & $\begin{array}{c}8.64 \\
(8.71)\end{array}$ \\
\hline
\end{tabular}

IR spectra

The structures of azo dyes were identified by IR spectra, it show intense bands appearing at $\left(1770\right.$ and $\left.1752 \mathrm{~cm}^{-1}\right)$ these peaks are attributed to carbonyl group abroad hydroxyl $(-0 \mathrm{H})$ peak observed with region 3200-3500 $\mathrm{cm}^{-1}$, the low frequency and the broadening of these bonds suggest that these dyes having a strong hydrogen bonding $(\mathrm{O}-\mathrm{H} \ldots \ldots . \mathrm{N})$ in the solid state ${ }^{16,17}$. The peak appearing in the region $1630-1625 \mathrm{~cm}^{-1}$ are attributed to $v(\mathrm{C}-\mathrm{N})$ stretching vibration. The band belonging to $v(\mathrm{~N}-\mathrm{H})$ stretching vibration is not observed probably due to overlapping with the broad hydroxyl peak. The other characteristic peaks of dyes are given in Table 2 . These data are in agreement with those previously reported for similar compound ${ }^{18-20}$.

Table 2. The IR spectral data of the azo-dyes ( $\mathrm{KBr}$ disk)

\begin{tabular}{cccccc}
\hline Compd. & $\begin{array}{c}v \mathrm{NH} \& \mathrm{OH} \\
\text { str. }\end{array}$ & $\begin{array}{c}v \mathrm{C}-\mathrm{N} \\
\text { str. } \mathrm{cm}^{-1}\end{array}$ & $\begin{array}{c}v \mathrm{C}=\mathrm{O} \\
\text { str. } \mathrm{cm}^{-1}\end{array}$ & $\begin{array}{c}v \mathrm{~N}=\mathrm{N} \\
\text { str. } \mathrm{cm}^{-1}\end{array}$ & $\begin{array}{c}v \mathrm{O}=\mathrm{S}=\mathrm{O} \\
\text { Asy/Sym }\end{array}$ \\
\hline $\mathrm{L}_{1}$ & $3500-3350 \mathrm{~b}$ & $1325 \mathrm{w}$ & $1670 \mathrm{~s}$ & $1429 \mathrm{w}$ & $1365 \mathrm{w}$ \\
$\mathrm{L}_{2}$ & $3300-3200 \mathrm{~b}$ & $1355 \mathrm{w}$ & $1658 \mathrm{~s}$ & $1415(\mathrm{w})$ & - \\
$\mathrm{L}_{3}$ & $3450-3250 \mathrm{~m}$ & $1332 \mathrm{w}$ & $1652 \mathrm{~s}$ & $1406 \mathrm{~s}$ & - \\
$\mathrm{L}_{4}$ & $3350-3300 \mathrm{~b}$ & $1323 \mathrm{w}$ & $1610 \mathrm{~s}$ & $1432 \mathrm{w}$ & - \\
$\mathrm{L}_{5}$ & $3500-3300 \mathrm{~b}$ & $1375 \mathrm{w}$ & $1656 \mathrm{~s}$ & $1433 \mathrm{w}$ & $1300 \mathrm{w}$ \\
\hline
\end{tabular}

\section{NMR spectra}

$b=$ board $s=$ strong $m=$ medium $w=$ weak

The structure of the compounds under study is investigated on the basis of ${ }^{1} \mathrm{H}$ NMR spectra (Table 3). The data shows two signals at $6.6-8.5 \mathrm{ppm}$ which can assigned to the protons of benzene $\operatorname{ring}^{21,22}$, compounds (Figure $1 \& 2$ ), shows signal at low field $(\delta \approx 10.5 \mathrm{ppm}$ ) which can be assigned to the proton of $\mathrm{NH}$ or $\mathrm{OH}$, since the proton signal of the hydrogen bonded $\mathrm{NH}$ must appear at low field. This supports the IR suggestion of the possibility for the structure of these compounds. 
Table 3. ${ }^{1} \mathrm{H}$ NMR spectra of azo compounds

\begin{tabular}{ll}
\hline Compd. & \multicolumn{1}{c}{$\boldsymbol{\delta}, \mathrm{ppm}$} \\
\hline $\mathrm{L}_{1}$ & $2.02\left(\mathrm{~S}, 3 \mathrm{H}, \mathrm{CH}_{3}\right), 6.9-7.9(\mathrm{~m}, 6 \mathrm{H}, \mathrm{Ar}-\mathrm{H}), 7\left(\mathrm{~S}, 1 \mathrm{H}, \mathrm{SO}_{3} \mathrm{H}\right), 9.8(\mathrm{~S}, 1 \mathrm{H}, \mathrm{NH})$, \\
& $10.7(\mathrm{~S}, 1 \mathrm{H}, \mathrm{OH})$ \\
& \multicolumn{1}{c}{$\mathrm{I}_{2}$} \\
& $2.02\left(\mathrm{~S}, 3 \mathrm{H}, \mathrm{NH}-\mathrm{C}-\mathrm{CH}_{3}\right), 6.5-8.2(\mathrm{~m}, 6 \mathrm{H}, \mathrm{Ar}-\mathrm{H}), 2.4\left(\mathrm{~S}, 3 \mathrm{H}, \mathrm{COCH}_{3}\right), 9.65$ \\
& $(\mathrm{~S}, 1 \mathrm{H}, \mathrm{NH}), 9.9(\mathrm{~S}, 1 \mathrm{H}, \mathrm{OH})$ \\
$\mathrm{L}_{3}$ & $2.03\left(\mathrm{~S}, 3 \mathrm{H}, \mathrm{CH}_{3}\right), 6.6-8(\mathrm{~m}, 6 \mathrm{H}, \mathrm{Ar}-\mathrm{H}), 9.8(\mathrm{~S}, 1 \mathrm{H}, \mathrm{NH}), 10.1(\mathrm{~S}, 1 \mathrm{H}, \mathrm{OH})$ \\
$\mathrm{L}_{4}$ & $2.02\left(\mathrm{~S}, 3 \mathrm{H}, \mathrm{CH}_{3}\right), 6.6-8.5(\mathrm{~m}, 6 \mathrm{H}, \mathrm{Ar}-\mathrm{H}), 6.7(\mathrm{~S}, 1 \mathrm{H}, \mathrm{NH}), 9.9(\mathrm{~S}, 1 \mathrm{H}, \mathrm{OH})$ \\
$\mathrm{L}_{5}$ & $2.02\left(\mathrm{~S}, 3 \mathrm{H}, \mathrm{CH}_{3}\right), 6.6-7.9(\mathrm{~m}, 6 \mathrm{H}, \mathrm{Ar}-\mathrm{H}), 7.31\left(\mathrm{~S}, 2 \mathrm{H}, \mathrm{SO}_{2} \mathrm{NH}_{2}\right)$, \\
& $9.67(\mathrm{~S}, 1 \mathrm{H}, \mathrm{NH}), 9.9(\mathrm{~S}, 1 \mathrm{H}, \mathrm{OH})$ \\
\hline
\end{tabular}

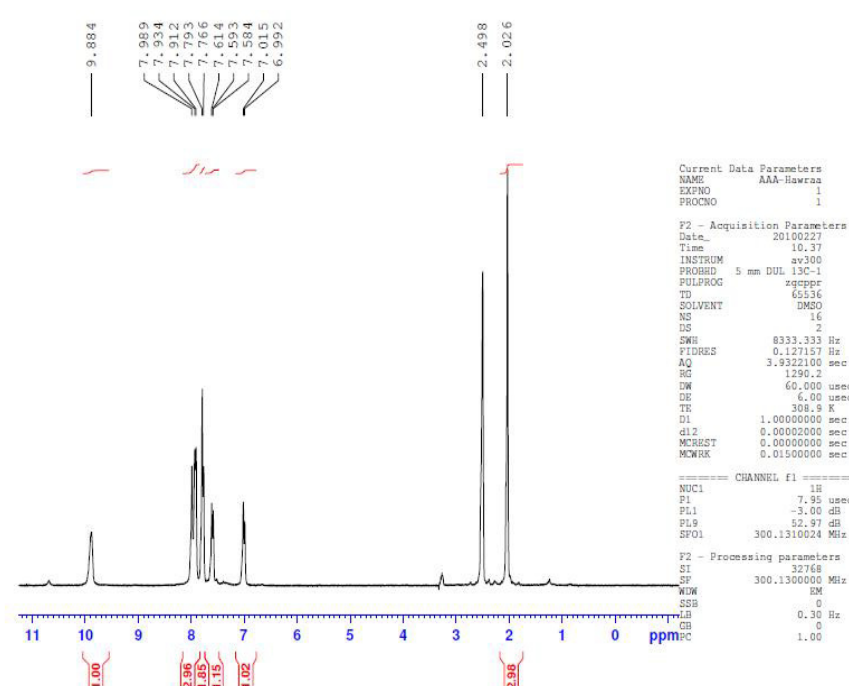

Figure 1. NMR spectra of $\mathrm{L}_{1}$

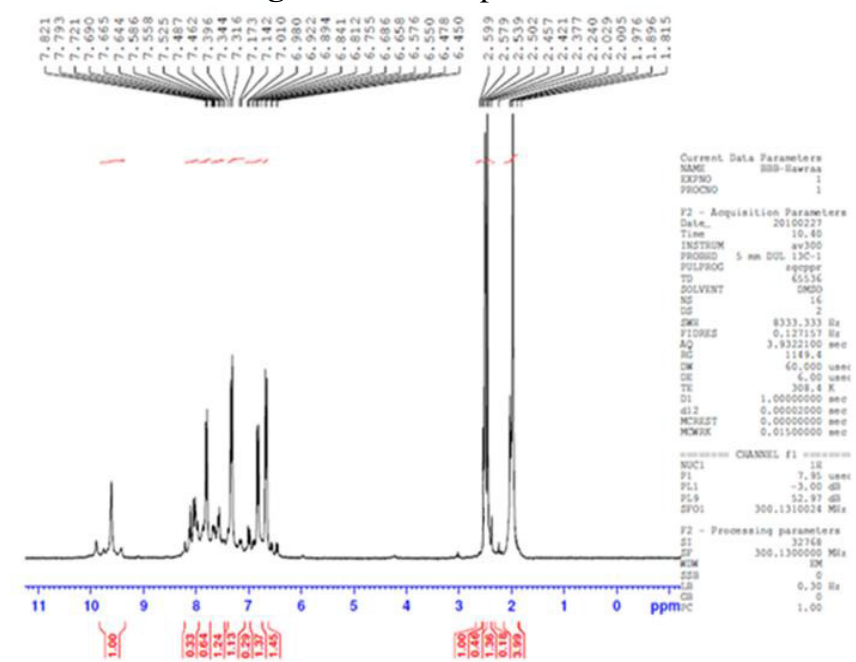

Figure 2. ${ }^{1} \mathrm{H}$ NMR spectra of $\mathrm{L}_{2}$ 


\section{Electronic absorption spectra}

The electronic absorption spectral of new dyes involve the absorption band due various electronic transitions liable to occur within the molecules such as bands due to localized excitation of the in $\pi$-electron within the aromatic moieties attached to azo group which lie at $240-260 \mathrm{~nm}$, may be attributed to $\pi \rightarrow \pi^{*}$ transition of benzenold moiety of compounds. The second band observed in the region of 290-295 nm is attributed to $n \rightarrow \pi^{*}$ electronic transition of $\mathrm{N}=\mathrm{N}$ - group. The third band appearing in the visible region at $(515,330,480.390 \& 500 \mathrm{~nm})$ for dyes $L_{1}-L_{5}$ respectively can be assigned to $\pi \rightarrow \pi^{*}$ transition involving the whole electronic system of the azo dyes influenced by inter-molecular charge transfer character ${ }^{23}$.

\section{Ionization and protonation constants of dyes}

Figure 3 show the electronic spectra of $\mathrm{L}_{1}$ at varying $\mathrm{pH}$ values (0.7-12).

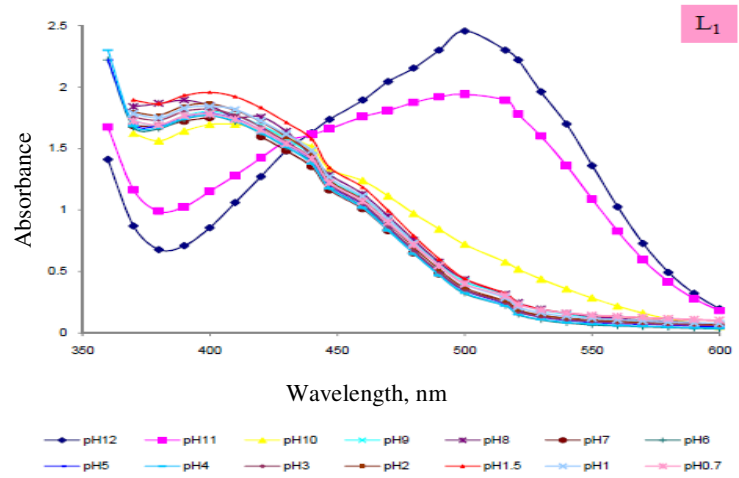

Figure 3. Absorbance $\mathrm{pH}$ for $\mathrm{L}_{1}$

Scheme 2 show the suggested mechanism for ionization and protonation of dyes, which show two isopiestic points are due to ionization and two isopiestic points are due to protonation of dyes in acidic and basic medium

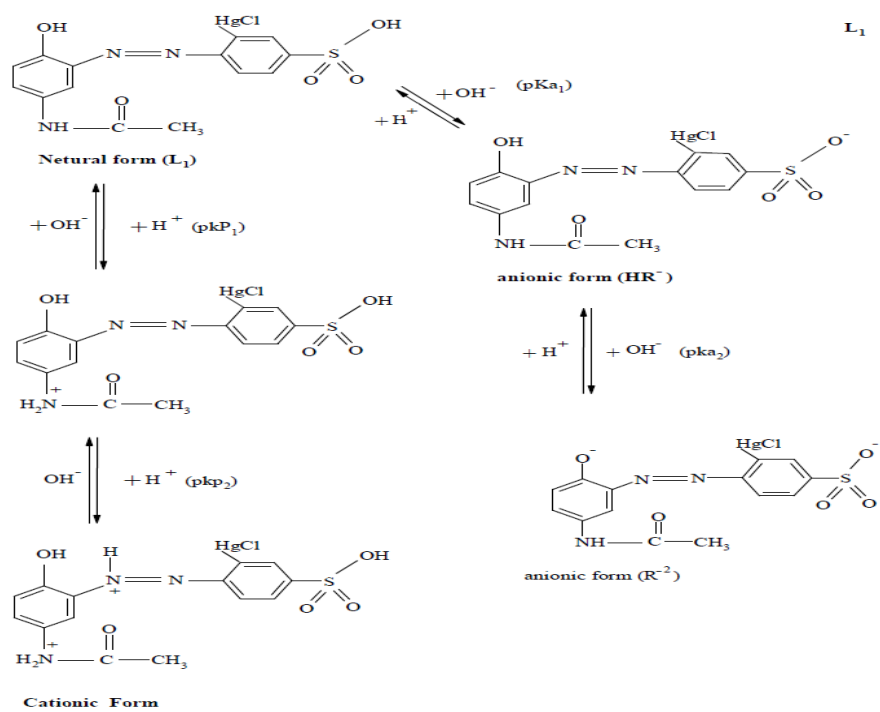

Scheme 2. The suggested mechanism for ionization and protonation of dyes 
The protonation and ionization constants $\left(\mathrm{pK}_{\mathrm{p}}\right.$ and $\mathrm{pK}_{\mathrm{a}}$ ) of dyes were determined from their spectral behavior in buffer solution of varying $\mathrm{pH}$ from the absorbance-pH curves at fix $\lambda$ (Figure 4). The $\mathrm{pK}_{\mathrm{a}}$ and $\mathrm{pK}_{\mathrm{p}}$ values were determined by using of half height method ${ }^{24}$ as shown in Table 4.

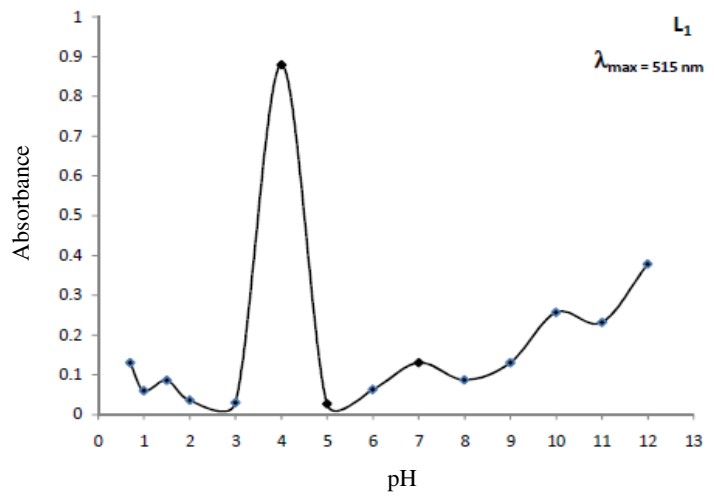

Figure 4. Absorbance $\mathrm{pH}$ for $\mathrm{L}_{1}$

Table 4. The ionization and protonation constants of dyes

\begin{tabular}{ccccccc}
\hline & $\lambda_{\max ,} \mathrm{nm}$ & $\mathrm{pKp} 1$ & $\mathrm{pKp} 2$ & $\mathrm{pKp} 3$ & $\mathrm{pKa} 1$ & $\mathrm{pKa} 2$ \\
\hline $\mathrm{L}_{1}$ & 515 & 1.4 & 3.5 & - & 6.2 & 9.3 \\
$\mathrm{~L}_{2}$ & 330 & 3.5 & - & - & 7.8 & 10.5 \\
$\mathrm{~L}_{3}$ & 480 & 4.5 & - & - & 6.5 & 9.8 \\
$\mathrm{~L}_{4}$ & 390 & 3.2 & 5.6 & - & 7.7 & - \\
$\mathrm{L}_{5}$ & 500 & 1.4 & 3.5 & 6 & 9.2 & - \\
\hline \multicolumn{6}{l}{$K_{a}=$} \\
\end{tabular}

\section{Complex formation studies}

Complex dyes $\mathrm{L}_{1} \& \mathrm{~L}_{5}$ with copper(II) $\left(\mathrm{C}_{1} \& \mathrm{C}_{2}\right)$ were identified optimum conditions for the composition of these complexes (time, $\mathrm{pH}$ and sequence of addition effects).

\section{Time effect}

It was found the two complexes $\mathrm{C}_{1} \& \mathrm{C}_{2}$ are of high stability because of stable absorbance measurements. The more intense color was for in the region of (1- $40 \mathrm{~min})$ and (1-120 $\mathrm{min}$ ) with respect of $\mathrm{C}_{1} \& \mathrm{C}_{2}$. The color is stable over night for both two complexes.

pH effect

By using of acetate and universal buffer solution ( $\mathrm{pH}=1-13)$. The spectra of $\mathrm{C}_{1} \& \mathrm{C}_{2}$ were studied in wavelength range of $(360-600 \mathrm{~nm})$. It was found that the $(\mathrm{pH}=8)$ of buffer solution is the suitable for forming both $\mathrm{C}_{1} \& \mathrm{C}_{2}$ complexes (Figure 5).

\section{Sequence of addition}

The best sequence of addition for giving highest absorbance for both $\mathrm{C}_{1} \& \mathrm{C}_{2}$ complexes is Metal $+\mathrm{pH}_{8}+$ Dye.

The acid-base properties of the ligands $\left(\mathrm{L}_{1} \& \mathrm{~L}_{5}\right)$ facilitate the investigation of the coordinating behavior of these ligands toward the copper ion $\left(\mathrm{Cu}^{\mathrm{II}}\right)$. Therefore the mechanism of complexation is based on hydrogen ion liberation. 


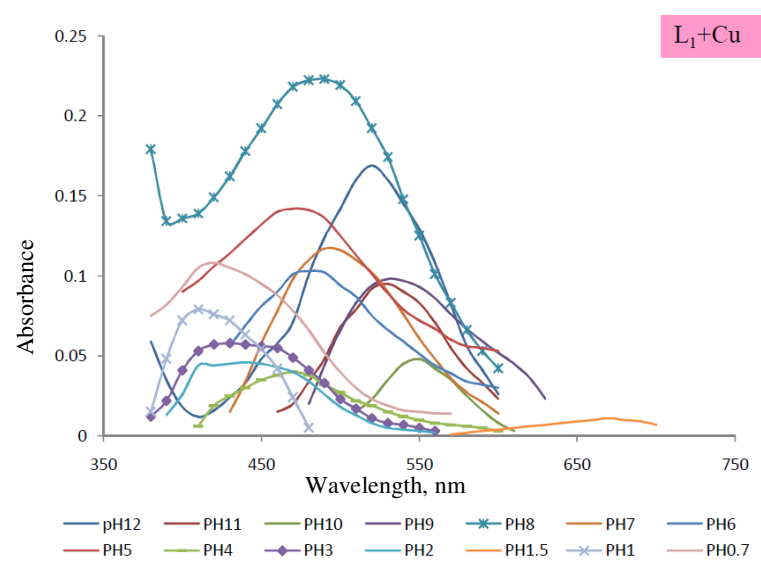

Figure 5. Absorbance $\mathrm{pH}$ for $\mathrm{C}_{1}$

The composition (stoichiometry) of the complexes was determined by the continuous variation and molar ratio methods. Both showed that the ratio of 1:1 and 1:2 (M:L) for both complexes.

The calibration curve shows that Beers law is obeyed in the concentration range of (0-15.25 $\left.\mu \mathrm{g} \mathrm{mL}^{-1}\right)$ and $\left(0-11.43 \mu \mathrm{g} \mathrm{mL}^{-1}\right)$ for complex of $\mathrm{L}_{1}$ and $\mathrm{L}_{5}$ with $\mathrm{Cu}(\mathrm{II})\left(\mathrm{C}_{1}\right.$ and $\left.\mathrm{C}_{2}\right)$ respectively. Table 5 shows the values obtained that represented by $\lambda_{\max }(\mathrm{nm})$, the molar absorbitivity coefficient $\left(\varepsilon\right.$ L.mol $\left.{ }^{-1} \cdot \mathrm{cm}^{-1}\right)$ and sensitive index $\left(\mathrm{s} \mu \mathrm{g} . \mathrm{cm}^{-2}\right)$, with higher precision that represented by the results of standard deviation (S.D), with high linearity of Beer's law which represented by the correlation coefficient ${ }^{\circledR}$ which is nearly unity and the detection limit (DL $\mu \mathrm{g} . \mathrm{mL}$ ) of the complexes $\mathrm{C}_{1}$ and $\mathrm{C}_{2}$.

Table 5. Some results obtained from Beer's law

\begin{tabular}{cccccccc}
\hline Compd. & $\Lambda_{\max }$ & $\begin{array}{c}\varepsilon \\
\text { L.mol }\end{array}{ }^{-1} . \mathrm{cm}$ & S.D & $\begin{array}{c}\mathrm{S} \\
\mu \mathrm{g} . \mathrm{cm}^{-2}\end{array}$ & $\begin{array}{c}\mathrm{DL} \\
\mu \mathrm{g} \cdot \mathrm{mL}^{-1}\end{array}$ & $\mathrm{r}$ & Beer's law limit \\
\hline $\mathrm{C}_{1}$ & 520 & 7302.3 & 0.021 & 0.0087 & 0.76 & 0.9946 & $15.25 \mathrm{ppm} \mathrm{Cu}$ \\
$\mathrm{C}_{2}$ & 530 & 6097.3 & 0.026 & 0.0104 & 0.56 & 0.9929 & $11.43 \mathrm{ppm} \mathrm{Cu}$ \\
\hline
\end{tabular}

\section{The stability of the complexes}

The stability constants of complexes of copper with azodyes ligand were calculated using corresponding solutions method (by aid of half- value method) ${ }^{24}$. This method required two series of solutions of total metal ion concentration $\mathrm{C}_{1 \mathrm{M}}$ (concentrated series) and $\mathrm{C}_{2 \mathrm{M}}$ (diluted series) and varying ligand concentrations $\mathrm{C}_{1 \mathrm{~L}}$ and $\mathrm{C}_{2 \mathrm{~L}}$, then the diluted series was multiplied by the factor $\left(\mathrm{C}_{1 \mathrm{M}} / \mathrm{C}_{2 \mathrm{M}}\right)$. The corresponding solutions are those which have the same absorbance at different ligand concentration. From the absorbance $-C_{L}$ plots (Figures $6 \& 7$ ) from many pairs of $\mathrm{C}_{1 \mathrm{~L}}$ and $\mathrm{C}_{2 \mathrm{~L}}$ values, $\mathrm{n}$ (complex formation function) and [L] free ligand concentration can be determined.

$$
\hat{N}=\left(C_{1 L}-C_{2 L}\right) /\left(C_{1 M}-C_{2 M}\right),[L]=\left(C_{1 M} C_{2 L}-C_{2 M} C_{1 L}\right) /\left(C_{1 M}-C_{2 M}\right)
$$

By using the half value method the $\log \beta_{1}$ and $\log \beta_{2}$ are obtained from a plot of $n$ against $\mathrm{pL}$, when $\mathrm{n}=0.5$ gives $\log \beta_{1}\left(\log \mathrm{K}_{1}\right)$ and $\mathrm{n}=1.5$ gives $\log \beta_{2}\left(\log \mathrm{K}_{1}+\log \mathrm{K}_{2}\right)$. It was found that $\log \beta_{1}$ values of $C_{1} \& C_{2}$ are $5.55 \& 3.79$ respectively and $\log \beta_{2}$ values of $C_{1}$ $\& \mathrm{C}_{2}$ are $9.4 \& 6.81$ respectively. 


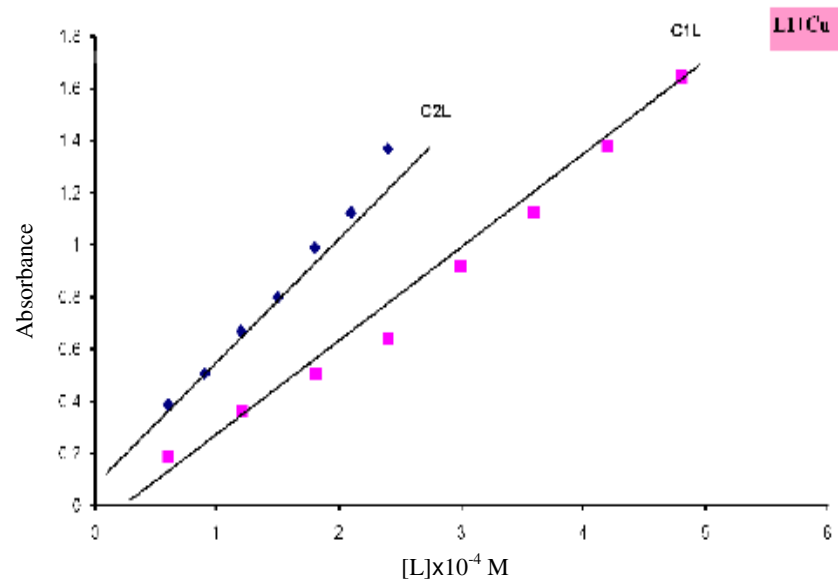

Figure 6. Absorbance $C_{L}$ plot of $C_{1}$

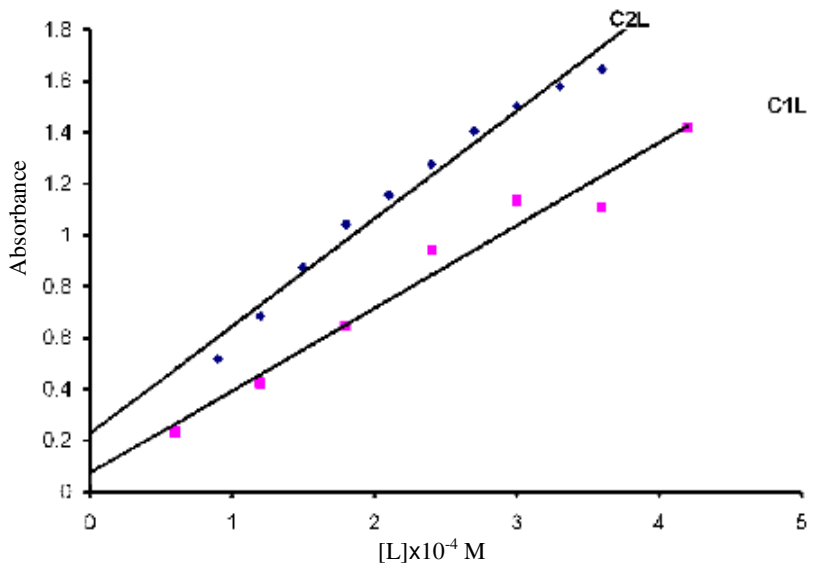

Figure 7. Absorbance $\mathrm{C}_{\mathrm{L}}$ plot of $\mathrm{C}_{2}$

\section{Conclusion}

In this study we have reported the synthesis of new mercerized azodyes by reaction of paracetamol (4-acetamido phenol) with 2-mercury chloride-4-X-aniline. The structural characterization of the azo compounds were made by using the elemental analysis, NMR, IR and UV spectral techniques. Ionization and protonation constants of dyes were calculated from electronic absorption spectral. The stability constants of complexes of copper with azodyes ligand were calculated using Corresponding Solutions method (by aid of half- value method).

\section{References}

1. Malik G M and Zadafiya S K R. Der Chemica Sinica, 2010, 1(3), 15-21.

2. Skeltonm R, Duboise F and Zenobi R, Anal Chem., 2000, 72(7), 1707-1710.

3. Savic J and Vasic V, Acta Chim Slov., 2006, 53, 36-42.

4. Hitendra M Patel, Der Chemica Sinica, 2012, 3(1), 175-181. 
5. Bhavesh P Dave1 and Purvesh J Shah, Der Chemica Sinica, 2012, 3(6), 1343-1347.

6. Hart K, Oforka N C and James A O, Adv Appl Sci Res., 2011, 2(4), 14-20.

7. Dong Y, Chen J, Li C and Zhu H, Dyes Pigments, 2007, 73, 261.

8. Nowik W, Encyclopedia of Separation Sciences, Academic press, London, 2000, 2602.

9. Casanova J, Alzuet G, Borras J, Timoneda J, Garcia-Granda S and Candano-Gonzalez I, J Inorg Biochem., 1994, 56(2), 65-76.

10. Goodman L S and Gilman A, The Pharmacological Basis of Therapeutics, $4^{\text {th }}$ Edn., MacMillian, New York,1970, 1111.

11. Sahebalzamani H, Ghammamy H, Mehrani K and Salimi F, Der Chemica Sinica, 2010, 1(1), 67-72.

12. Attar S, Nelson J H and Fischer J, Organometallics, 1995, 14, 4776.

13. Volna F, Odlerovb Z.and Lacova M, Immunology, 1973, 22, 223.

14. Sawi E, EL-Shahat M F, Moti F A and EL-Messary S, J Chem Soc Pak., 1984, 6, 77-82.

15. Joshi P, Pareek N, Chauhan R S and Gaswamil A K, Rasayn J Chem., 2010, 3, 445-449.

16. Kiek B and Grup R, Turk J Chem., 2008, 32, 9

17. Masoud M S and Muhamed G B, J Korean Chem Soc., 2002, 2, 99-116.

18. Gup R and Kirkon B, Spectro Chim Acta A, 2006, 64, 89.

19. Gup R and Giziroglu E, spectro Chim Acta A, 2006, 65, 719-726.

20. Ali A A, Fahad T A, Rusen I A and Mohammed I K J Basrah Researches (Sciences) 2010, 36(4A), 60-65.

21. Hameed S A, Jordan J Chem., 2007, 2(2), 133-144.

22. Jarallah H M and Hadi J S, J Basrah Researches (Sciences), 2012, 38(1A), 147-157.

23. Fahad T A, Ali A A and Mohammed I K, J Basrah Researches (Sciences), 2011, 37(4A), 131-140.

24. Wadi N M, Ali A A and Saeed B A, J Basrah Researcher (Sciences), 1993, 10, 77. 